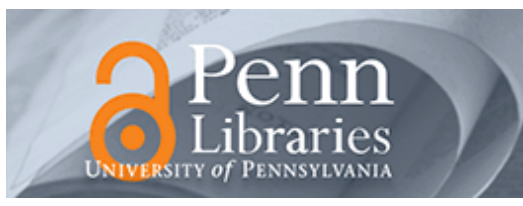

University of Pennsylvania ScholarlyCommons

Wharton Pension Research Council Working Papers

Wharton Pension Research Council

$10-1-2011$

\title{
Public Pension Pressures in the United States
}

Olivia S. Mitchell

The Wharton School, University of Pennsylvania, mitchelo@wharton.upenn.edu

Follow this and additional works at: https://repository.upenn.edu/prc_papers

Part of the Economics Commons

Mitchell, Olivia S., "Public Pension Pressures in the United States" (2011). Wharton Pension Research Council Working Papers. 185. https://repository.upenn.edu/prc_papers/185

This paper is posted at ScholarlyCommons. https://repository.upenn.edu/prc_papers/185

For more information, please contact repository@pobox.upenn.edu. 


\title{
Public Pension Pressures in the United States
}

\begin{abstract}
This paper discusses why public pensions have warranted so much interest of late, focusing on their financing status and reform options. Many state pension plans are underfunded, and while they can pay promised benefits for some years, there is also enormous cross-state heterogeneity and several state pension plans will require substantial new revenue and/or benefit cuts to bring them to long-term solvency. What remains to be seen is how the burden of returning the plans to financial health will be borne, and how key stakeholders will implement reforms in these systems if they are to return to viability before time runs out.
\end{abstract}

\section{Disciplines}

Economics 


\title{
Public Pension Pressures in the United States
}

\author{
Olivia S. Mitchell
}

October 2011

\author{
PRC WP2011-21 \\ Pension Research Council Working Paper \\ Pension Research Council \\ The Wharton School, University of Pennsylvania \\ 3620 Locust Walk, 3000 SH-DH \\ Philadelphia, PA 19104-6302 \\ Tel: 215.898.7620 Fax: 215.573.3418 \\ Email: prc@wharton.upenn.edu \\ http://www.pensionresearchcouncil.org
}

The author acknowledges research support from the Pension Research Council/Boettner Center at the Wharton School of the University of Pennsylvania, and helpful comments from Robert Clark and Peter Conti-Brown. All findings, interpretations, opinions and conclusions of this paper represent the views of the author and not those of the Wharton School or the Pension Research Council, or any other institution with which the author is affiliated. (C) 2011 Mitchell and the Pension Research Council of the Wharton School of the University of Pennsylvania. All rights reserved. 


\begin{abstract}
This paper discusses why public pensions have warranted so much interest of late, focusing on their financing status and reform options. Many state pension plans are underfunded, and while they can pay promised benefits for some years, there is also enormous cross-state heterogeneity and several state pension plans will require substantial new revenue and/or benefit cuts to bring them to long-term solvency. What remains to be seen is how the burden of returning the plans to financial health will be borne, and how key stakeholders will implement reforms in these systems if they are to return to viability before time runs out.
\end{abstract}

\title{
Olivia S. Mitchell
}

Pension Research Council, The Wharton School, University of Pennsylvania mitchelo@wharton.upenn.edu 


\section{Public Pension Pressures in the United States}

Olivia S. Mitchell

Of late, public employee pension plans have received a great deal of scrutiny and media attention. ${ }^{1}$ One reason is that some in the private sector are experiencing "pension envy" on learning that public pension benefits are often more generous than those paid to private sector employees. For instance, benefits on average replace $56 \%$ of pay for employees with 30 years of work in the public sector (66\% if they are not covered by Social Security), versus $46 \%$ for private defined benefit-covered workers (Clark, 2011). Another reason is that financial markets investors, rating agencies, and insurers - are devoting much more attention than ever before to the financing demands of public sector pensions plans when considering whether a state may be able to sustain, and surely to increase, efforts to borrow as a means of smoothing the deleterious impact of the financial crisis (Fitch 2011; Moody’s 2011; S\&P 2011). This chapter discusses why public pensions have warranted so much interest of late, devoting particular attention to their financing, funding status, recent developments, and reform options.

We show that many state pension plans will be able to pay promised benefits for some time, but there is enormous cross-state heterogeneity. Several states will surely require substantial new revenue soon or they will need to institute benefit cuts if they are to return their plans to long-term solvency. ${ }^{2}$ What remains to be seen is how the burden of returning the plans to financial health will be borne, and how key stakeholders will implement reforms in these systems, if they are to once again become viable before time runs out.

\footnotetext{
1 A Google search provided 65 million results in September of 2011.

${ }^{2}$ For lack of space we do not take up solvency issues facing federal employee pensions nor the national Social Security system; neither can we focus on municipal pension financing or public employee retiree health insurance obligations. For analysis of these see Clark and Morrill (2010, 2011), McElhaney (2009), Mitchell and Anderson (2009), and Mitchell and Hustead (2000).
} 


\section{A Brief Background on State Pension Plans}

Public sector pensions in the United States cover approximately 20 million public sector (non-federal) employees and around seven million retirees (Staman, 2011). The vast majority of U.S. public pension plans are of the defined benefit (DB) variety, where retiree payments are specified as a stream of periodic payments for life with the amounts based on retirees' salary and years of service. In contrast, most private-sector employees with pensions have defined contribution (DC) plans; in these, contributions are specified as a percent of pay, but no particular benefit payout is specified. ${ }^{3}$

Labor market analysts are in agreement that pensions are one of many forms of deferred compensation offered to enhance employers' ability to recruit, incentivize, and eventually retire employees. $^{4}$ The U.S. has had a rich tradition of offering pensions to public employees, beginning with disability pensions for the militia during the Colonial period (Clark et al., 2003; 2009; 2011). Thereafter, the U.S. Continental Congress established disability programs for members of the armed services during the Revolutionary era, which were later converted to oldage pension programs for veterans. In the mid- $19^{\text {th }}$ century, many U.S. cities provided benefits for their superannuated teachers, firefighters, police officers, and other public personnel, as part of a broad effort to reform civil service jobs and move them into a merit-based system rather than one based on patronage (Clark et al., 2003). Most federal employees were covered by

\footnotetext{
${ }^{3}$ For useful overviews of U.S. public pension plans see Mitchell (2000); Mitchell and Anderson (2009), Mitchell et al. (2000), and Mitchell and Hustead (2000); more recent studies include Pew Center (2010a, 2010b, 2011).

${ }^{4}$ Pensions are also a useful way for employees to save retirement in a tax-qualified vehicle (McGill et al., 2010).
} 
retirement pensions by 1930, though the federal approach to retirement provision has also evolved over time (Hustead and Hustead, 2001).

The first U.S. state credited with establishing a state-wide retirement plan is Massachusetts, which in 1922 began to cover general public employees (Craig, 2003). Thereafter, several states moved to implement pensions (mostly defined benefit plans) in response to the passage of the national Social Security Act in 1935 which explicitly excluded public sector employees. In 1950, an amendment to that Act permitted governmental units to enter Social Security; currently, public employees in seven states are still not included in the U.S. Social Security system. ${ }^{5}$

\section{The Structure of Public Sector Defined Benefit Plans}

Workers covered by DB pension promises receive compensation in the form of labor earnings as well as claims to future streams of pension payments in retirement. Accordingly, an employee accrues a future promise of benefits each year on the job, an accrual that constitutes a liability of the pension plan. Generally retirement benefits are determined by a formula (often collectively bargained), where payments rise with the worker's salary level, age and/or time on the job (tenure), retirement age, and perhaps other factors (Mitchell et al., 2000).

In the early 1900’s, few state pension plans were “funded” - few had accumulated assets sufficient to back the benefits accrued by active workers (Craig 2003). Indeed, most early plans were run on a “pay-as-you-go” model, where annual benefit payments were covered by annual employee and employer contributions, as well as dedicated taxes (e.g. property tax levies or one-

${ }^{5}$ States still not participating in Social Security include Alaska, Colorado, Louisiana, Maine, Massachusetts, Nevada, and Ohio. Additionally some local government workers do not participate including groups in California, Connecticut, Illinois, Kentucky, Missouri, and Texas (Clark 2011). In 1983 the right to withdraw from Social Security was revoked. 
time asset sales; c.f. Civic Federation, 2007). Over time, however, states began to link pension contribution levels to actuarial calculations, which meant that each participant's expected future pension payments would be calculated and - at least in principle - money would be set aside each year to finance those future benefits. To the extent that contributions were also invested, the pension fund's accumulated investment earnings were also used to pay benefits. From this perspective, then, the notion of a fully funded DB plan evolved: it was one that had, at any given date, sufficient money to pay all accrued vested benefits. ${ }^{6}$

The first states to thus structure their plans - sometimes referred to as "scientific" pension plans in the 1920's - were New Jersey, Ohio, and Vermont (Craig, 2003). A key rationale for using these actuarial calculations was to ensure that sufficient funds would be set aside to pay workers' accrued benefits. In practice of course, full funding is inherently a moving target: future benefit projections rely on assumptions about wage increases, labor turnover, mortality patterns, inflation, and other factors, and asset returns are also not reliably forecasted. Accordingly, DB plans must periodically adjust contributions and/or benefits so as to rectify funding shortages. ${ }^{7}$

\footnotetext{
6 This refers to vested benefits; vesting occurs when the worker has earned a legal right to the future benefit stream. In the corporate sector, this funding concept is called the termination or shutdown liability, referring to the ability of a plan to pay all promised benefits even if the plan sponsor were to shut down (PBGC, nd). The public sector has often used different accounting and financial reporting standards (GASB, 2006).

${ }^{7}$ Pension cost concepts to this end are described by Winklevoss (1993) among others. It must be noted that not everyone favors $100 \%$ funding of public pensions. From a practical viewpoint, the GAO (2008: 19) notes that funding at an 80 percent level might be sensible since "...it is unlikely that public entities will go out of business or cease operations as can happen with private sector employers, and state and local governments can spread the costs of unfunded liabilities over a period of up to 30 years under current GASB standards. In addition...it can be politically unwise for a plan to be overfunded; that is, to have a funded ratio over 100 percent. The contributions made to funds with "excess" assets can become a target for lawmakers with other priorities or for those wishing to increase retiree benefits.” Bohn (2011), among others, offers theoretical arguments pro and con.
} 


\section{Recent Concerns about State Pension Plans}

A major debate has recently exploded regarding public sector pension problems, driven in part by the ongoing economic recession which drastically cut state tax collections by 30 percent in 2009 (and revenue streams have not recovered quickly; c.f. Cooper 2011). Consequently, many states face substantial budget challenges on many fronts due to extraordinary unemployment insurance bills, rising Medicaid expenditures due to aging populations, and the need to pay for major infrastructure improvements. Also, most state governments must balance their operating budgets, making it difficult to come up with the needed cash to remedy pension shortfalls at the same time that other pressing fiscal needs have emerged. ${ }^{8}$

These exigencies are now competing with the need to hike contributions to meet public pension funding requirements. Such shortfalls were partly the result of the approximately $\$ 1$ trillion in losses sustained by plan assets during the financial market implosion (Munnell et al., 2011a). In addition, public sector employees have been retiring in record numbers, increasing the drain on pension assets sooner than expected. ${ }^{9}$ Public plans have also gotten into financial trouble for longer-standing reasons, including the fact that states have historically cut pension contributions and raised benefit promises in good economic times, rather than taking advantage of robust periods to build up a financial cushion to protect against downturns (Schieber, 2011).

\footnotetext{
${ }^{8}$ An active discussion is underway regarding the potential for state bankruptcy in the wake of the crisis; c.f. Skeel (2011). Barclay's (2011) noted that pension underfunding plays a role in this process, since Standard \& Poor's downgraded New Jersey's general obligation (GO) rating to AA- from AA, citing its concern about the state's pension system underfunding; they also indicated that Moody's expressed concern regarding Illinois state bonds due to pension funding shortfalls.

${ }^{9}$ For instance, retirement rates for Ohio public school teachers rose between 2009 and 2010 by 20 percent, and 50 percent for highway patrol officers, as workers responded to uncertainty about the state's pension underfunding (Rowl, 2011).
} 
Public plan contributions have also fallen short of what they should have been: for instance, according to Greenhouse (2011), the 50 states together owed $\$ 117$ billion to their pension plans in 2009 but in fact only contributed $\$ 73$ billion. Contribution shortfalls of this nature have persisted because state DB plans follow rules set by their legislatures rather than by a centralized accounting authority; this permits politicians to adjust payment targets in times of fiscal stringency. ${ }^{10}$

Public pensions have also been roundly critiqued of late regarding how they measure their assets and liabilities. On the asset side, rather than reporting the market value or the amount for which the assets could be sold in the capital market, public DB pensions are permitted to "smooth" the time period over which the valuation is conducted (most public plans smooth assets over five or more years; Barclays, 2011). While such smoothing does reduce reported plan funding volatility, it also means that, after a substantial market crash such as the recent one, reported asset values and returns do not portray a plan's economic funding status as of any given moment. For instance, at year-end 2009, the 50-state total of assets computed using actuarial values exceeded the assets’ market value by over 20\% (Barclay’s 2011).

Another thorny issue has to do with how the public pension plan liabilities are measured. This is difficult, because DB plan liabilities are of very long duration - they include the sum of benefits that must be paid this year, next year, the year afterward, and so forth, until the last surviving pension plan participant dies. If we define $\mathrm{B}_{\mathrm{t}}$ as the retirement benefits a DB plan is

\footnotetext{
${ }^{10}$ The Government Accounting Standards Board (GASB) requires public sector employers to report annual required contribution (ARC) amounts, but as Barclay's (2011: 44) notes, this "is not a government funding requirement.... While the ARC prescribes what an employer should contribute to cover current (normal) costs incurred and pay down the UAAL [unfunded liabilities], actual contributions do not always equal the ARC because governments are free to determine their own funding schedules. In addition, during times of fiscal stress, states may choose to defer or cut their pension contributions.” (italicized phrase added).
} 
obligated pay to all retirees in any given year t; $r$ the discount rate used to convert current future benefits into today's dollars; and assuming that last possible year the final plan survivor (including spouses) will die is 90 years from now, then the expected present value of the benefit stream may be expressed as follows: ${ }^{11}$

$$
\text { EPV Benefits }=\mathrm{B}_{0}+\mathrm{B}_{1} /(1+r)+\mathrm{B}_{2} /(1+r)^{2} \ldots+\mathrm{B}_{90} /(1+r)^{90}
$$

Naturally, many assumptions are required to forecast future DB plan obligations, including wage growth and inflation, turnover and retirement patterns, mortality improvements, and so forth. ${ }^{12}$ Yet an underappreciated and very powerful factor driving the liability measure is $r$, the discount rate. For corporate pensions, the U.S. government requires private DB plans to use discount rates consistent with the cost of corporate borrowing (the corporate yield curve). By contrast, public pension accounting permits DB plans to discount future benefit promises at the projected rate of return expected on plan assets, rather than what it would cost the state to borrow. What this means is that public DB plan sponsors today regularly use discount rates higher than eight percent, despite the fact that they will probably not earn long-term asset returns of this magnitude anytime soon. ${ }^{13}$

As is evident from the formula above, when a DB plan sponsor selects a high discount rate for computing funding levels, this mechanically lowers plan measured liabilities. What might be less obvious is that seemingly small changes in $r$ have profound implications for pension funding and contribution requirements. For instance, Winklevoss (1993) noted that a

\footnotetext{
${ }^{11}$ We refer the interested reader to McGill et al. (2010) for a more detailed discussion of plan cost methods.

12 Another issue worth mentioning here is that public plan liabilities often are broader than corporate pension liabilities, in that the former include future or projected benefits as well as accrued vested benefits earned as a function of salary and service to date.

${ }^{13}$ Wilshire (2011) expects the median state pension fund to earn $6.5 \%$ per year on its investments, assuming asset allocations of $64 \%$ equity (31\% US, 18\% non-US, 6\% real estate, and $9 \%$ private equity), and 36\% fixed income (27\% US, 9\% other) .
} 
single percentage point increase in the discount rate shrinks measured plan actuarial liabilities by 15-20 percent; Munnell et al. (2011a, b) shows that raising the discount rate by two percentage points, from 8 to 10 percent, staves off the date at which a public plan will exhaust its assets and hence be unable to pay benefits - by a dozen years. In other words, selecting a high discount rate will mean substantially lower pension liabilities - implying, in turn, lower contributions required to finance retiree promises. ${ }^{14}$

To illustrate the stakes in this highly-charged debate, Table 1 reports how state DB plan funding projections respond to different discount rate assumptions. In the left-most column, liabilities are \$2.8 trillion when discount rates chosen by the states (usually 8\%) are used. The middle column uses the taxable municipal bond yield curve, and here liabilities are larger, at $115 \%$ of commonly-reported levels. The final column, where a Treasury bond yield curve is used, pegs state pension liabilities at 185\% of the first column (Rauh, 2010). Clearly, the choice of discount rate makes an enormous difference in measuring the size of benefits promised to retired workers. After subtracting out plan-reported asset levels, the net underfunding also varies rather dramatically: in the first column, underfunding using state discount rates amounts to $\$ 0.86$ trillion; in the second column, the estimate is half again as large with the muni-bond rate; and using Treasury rates boosts public pension underfunding to $\$ 3.26$ trillion. ${ }^{15}$ In other words, using the state-selected discount rates, the ratio of state pension assets to liabilities (A/L) comes to $69 \%$, indicating an estimated shortfall of almost one-third overall. But the $\mathrm{A} / \mathrm{L}$ ratio is only

\footnotetext{
${ }^{14}$ For instance, when New York State raised its assumed interest rate in 1991 from 8 to 8.75 percent, this lowered the government's annual required contribution by \$325 million (Hsin and Mitchell, 1994).

15 This pattern is similar to those reported by the U.S. Congressional Budget Office (Russek, 2011) and Munnell et al. (2011).
} 
$37 \%$ using the least risky rate, implying that assets fall short of promised benefits by almost twothirds.

\section{Table 1 here}

The economic rationale for using a less-risky discount rate is that public pension benefits are often deemed to be very secure promises. In fact they are frequently guaranteed by state constitutions and backed by the full faith and credit of the state tax base (Staman, 2011; NEA 2004). ${ }^{16}$ For this reason, financial economists argue that the discount rate for valuing future public pension benefits should be close to a risk-free Treasury rate (Brown and Wilcox, 2009; Novy-Marx and Rauh, 2011a). Furthermore, conformity with private pension accounting would suggest that a state's borrowing rate is a better assumption than the (usually much higher) expected return on assets. Also, from the perspective of transparency, Wilcox (2008: 1) contends that "[s]ome have argued that because state and local governments do not exist to generate a profit, or because public plan sponsors cannot go out of business or be acquired by a competitor, market-based estimates are irrelevant for them. Others have argued that policymakers need other information aside from market-based estimates in order to make sound decisions on behalf of their constituents... [But] in order to be useful, an estimate of plan liabilities must provide an analytically sound answer to a coherent, well-specified question. Market-based estimates of plan liabilities meet that test.”

On the other hand, some actuaries and plan administrators continue to argue strongly in favor of the conventional approach. One reason is that it is believed to generate more stable

\footnotetext{
${ }^{16}$ The Little Hoover Commission noted that (2011: i): “[p]ension benefits promised to retirees are irrevocable, as are the promised benefits that current workers have accrued since their employment began. It also remains difficult to alter the theoretical, yet-to-be earned benefits for current workers. This situation, reinforced by decades of legal precedent, leaves little room for state and local governments to control mounting retirement costs, particularly when the only venue for change is the bargaining table.”
} 
contribution rates than the alternative (Segal, 2011) ${ }^{17}$ Another reason, according to Miller (2008: 2) is that "[b]y retaining the traditional practice of using reasonably probable investment returns as the basis for discounting future obligations... actuaries and accountants faithfully support the primary purpose of a public pension plan -- which is to establish a funding plan that has the best possible chance of equitably balancing the interests of today's taxpayers and tomorrow's retirees. Many ... would agree with me that using risk-free rates of return to value public plans (which enjoy a long-term horizon and capacity to prudently assume equity risks) will almost assuredly over-burden today's taxpayers. Such an MVL regime would perversely shift the entire normal market risk premium to the benefit of future generations at the expense of their forebears." ${ }^{\prime 18}$

But change is in the wind. Several states are currently litigating cases that would allow legislatures to alter and amend pension benefit and contribution formulas; these may render public pension promises less immutable than anticipated in the past. ${ }^{19}$ New rules are also being developed by the Government Accounting Standards Board (GASB 2011) which will use a bond discount rate for underfunded pension liabilities (though expected asset returns will still be used to value funded plan liabilities; Segal 2011). Meanwhile, though two of the major rating agencies, Standard \& Poors and Moody's, are still using reported funding ratios using state-

${ }^{17}$ See also Angelo et al. (2010); Lav and McNichol (2011); and SOA (2006).

${ }^{18}$ Maurer et al. (2009) develop an explicit model to examine what asset allocation would minimize worst-case pension costs using a Monte Carlo framework and a stochastic present value approach, combined with a conditional value at risk measure. They show that funding public pension obligations requires being explicit about the level of risk that the plan fiduciary is willing to take on, which in turn requires explicit attention to risk-bearing by present and future generations.

${ }^{19}$ For a discussion of litigation underway on public plan benefit changes see Barclays (2011) and Snell (2011). Walsh (2011) reports that judges in Colorado and Minnesota have refused to hear complaints about reductions in the cost-of-living adjustments for public pension recipients. For a discussion of other reforms see Brown et al. (2011). 
determined discount rates, Fitch is moving toward more conservative rates to make plan funding rates comparable across states (Barclays, 2011; Fitch, 2011; Moody’s, 2011). It is also evident that public pension discount rate choices have been selected opportunistically: for instance, states experiencing fiscal problems reduce required contribution flows by selecting higher pension discount rates (Hsin and Mitchell, 1994), and less well-funded plans are more than 2.5 times more likely to use a discount rate greater than eight percent, compared to better funded plans (Park, 2009). While the great discount rate debate is far from over, it seems probable that the economic perspective will eventually prevail.

\section{How Important Is This?}

The debate over exactly which public pension underfunding measure to use ultimately boils down to what these shortfalls mean to stakeholders, and which stakeholders will be most affected when pension promises made to teachers, police, firefighters, and other state employees cannot be met. In the past, state pension contributions averaged $4 \%$ of annual state budgets, a level low enough that some argue there is little need for concern (Munnell et al. 2010). But this logic is flawed, since the historical experience does not reflect the large new financing shortfalls resulting from the financial crisis, recession, and other longer-term problems. For example Novy-Marx and Rauh (2011a) estimate that contributions to public pensions will need to rise more than three-fold, to $14 \%$ of public sector revenue, to achieve full funding over the next 30 years. Average contributions would have to rise to $41 \%$ of payroll, and on average this could amount to a per-household average tax increase of $\$ 1,400$ per year.

Of course attempting to raise taxes this much could have potentially very serious consequences. Some public sector entities are already finding it difficult to borrow in the capital 
market as a result of the economic and financial crisis, and rating agencies are now paying much closer attention to whether pension shortfalls are exacerbating this problem. Explicit state debt totaled \$2.4 trillion in 2010 (Mcguire 2011: 5), and many states face limited capacity to borrow further. It is also worth noting that the pension financing burden is not spread evenly. For instance, more than $20 \%$ of all general state transfers and revenues received by the State of Illinois are currently required to pay for pensions (Barclays 2011: 1). ${ }^{20}$ To amortize their shortfalls over the next 30 years, New Jersey and New York households would face immediate and continuing tax hikes of more than \$2,200 per household. California and Illinois residents would confront a yearly tax increase of over $\$ 1,900$; while at the low end, Indiana residents would need to pay only \$329 more per year in order to fund state pensions over the next three decades (Novy-Marx and Rauh, 2011c: 40). Many municipalities and even some states are also aware that raising taxes may shrink the tax base. ${ }^{21}$

If needed revenues are not raised, however, a large number of public plans is likely to run quite short on cash within the decade. Munnell et al. (2011a) estimate the exhaustion date for public plans under two scenarios, an "ongoing” framework assuming that plan sponsors pay the full costs required in future years, versus a "termination" framework assuming that benefit payments must rely solely on existing assets. If a relatively high $6 \%$ discount rate is assumed (yet one below what most plans currently use), they predict that public plans will exhaust their assets in 2022 on average if they terminated immediately and paid only already-accrued benefits. The exhaustion year is pushed back - but only slightly - to 2025, assuming that new contributions continue to flow in and benefit accruals continue to rise. Either way, these dates are

\footnotetext{
20 This figure includes pension benefits and debt service on pension obligation bonds.

21 For instance Epple and Shipper (1981) report that a large component of public pension shortfalls is capitalized in property prices.
} 
alarming, particularly for Baby Boomers expecting a pension cashflow for two to three decades in retirement. It is also striking that the exhaustion date forecasts are quite unresponsive to higher discount rates.

Table 2 here

There is also substantial variation around the averages, as illustrated in Figure 1. Here the projected dates of exhaustion for public pensions in Illinois, Indiana, Connecticut, and New Jersey will take place by 2020, along with Hawaii, Louisiana and Oklahoma. A dozen more states face cash strictures by 2025, with about the same number by 2030. States projected to be in better shape include Alaska, Florida, Nevada, New York, and North Carolina. It should be noted that these projections assume that investments return 8\% per year; moreover, the analysis does not take into account reforms already made as well as potential future changes (Angelo et al. 2010). But as we shall see, the reforms currently underway may not do much to remedy the problems at least for those facing most serious shortfalls.

Figure 1 here

\section{Reforms Underway}

In response to the fiscal pressures identified above, several public plan sponsors have proposed and implemented reforms that they hope will alleviate these pension pressures. As noted by the GAO (2011), one rather worrisome approach has been to tilt pension portfolios into riskier investments, in the hope of making higher expected returns. For instance, New Jersey's public pension council recently approved a one-third increase in the maximum permitted allocation to alternative investments including hedge funds and private equity (Tangel, 2011); Illinois and Pennsylvania's funds have been writing credit default swaps and international 
interest rate swaps (Harris 2010). Some states have also issued special pension obligation bonds (POBs) to generate cash which is then deposited in the pension system; nevertheless, this has proven an expensive way for some states to raise money. ${ }^{22}$ Even when these are admissible assets for pension plans, they also involve substantially more risk, and given extant underfunding, it is unclear if such investments are consistent with a well-thought out approach to pension risk management. ${ }^{23}$

An increasingly prevalent way to raise plan revenue involves asking employees to pay more for their own pensions. In 2010, a dozen states boosted employee pension contributions; to date in 2011, 14 states including Wisconsin and Florida have also legislated contribution increases (Greenhouse, 2011). ${ }^{24}$ The governor of New York in 2011 has requested a doubling of employee contribution rates from three to six percent of pay; in Oregon, the proposed hike is from zero to six percent.

Besides boosting investment returns and raising contributions, the only other way to reduce pension underfunding is to curtail expenditures. Of late, many such efforts have been set in motion (NASRA, nd). Changing the rules for retirees is usually seen as most difficult, though changes in cost-of-living adjustments clearly reduce the purchasing power of retiree benefits. ${ }^{25}$ Altering prospective benefits for existing workers is also difficult, since many state statutes and constitutions protect not only accrued but also prospective benefits for current employees. Also,

\footnotetext{
22 Barclay's (2011) reports that, if states were to issue \$700 B in 30-year debt at an interest rate of $6-7.5 \%$ to finance their public plans, annual debt service would amount to about $7-8 \%$ of state tax revenues.

23 In fact, some financial economists and actuaries have recommended otherwise (c.f. Black, 1989; Gold and Latter, 2009; Lucas and Zeldes, 2009; and Peskin, 2001; among others).

${ }^{24}$ For a detailed list of changes in 2011 to date, see Snell (2011).

${ }^{25}$ As noted above, Colorado, Minnesota, and South Dakota have recently sought to restrict costof-living adjustments (COLA); a full list of 2011 COLA changes appears in Snell (2011) and NASRA (nd).
} 
current employees are usually covered by collective bargaining contracts which require joint union/management agreement to bring about any change. For these reasons, it has been somewhat less difficult (and less controversial) to adjust benefit formulas for future employees those not yet hired. For instance, numerous states have raised the number of years required to vest in (gain a legal entitlement to) eventual benefits; in addition, the retirement age has been raised in several cases, along with the number of years required for unreduced benefits (Snell, 2011).

Some have proposed switching from a DB to a DC plan to reduce future benefit costs. To date, two states, Alaska and Michigan, have mandated DC plans for new hires; ten additional states offer as options either defined contribution or hybrid plans (mixed DB and DC). It is worth noting, however, that reducing costs for the not-yet-hired would not be expected to affect the already accrued benefits - also known as the legacy benefits - and their underfunding inherited from the past. ${ }^{26}$

At the end of the day, the size of the public pension shortfall remains dauntingly large and discouragingly expensive to fix. And few of the changes explored to date will help fill the gap very much, including changes in the cost-of-living escalators (COLAs) often applied to benefits post-retirement. According to Novy-Marx and Rauh (2011a: ii) a "one percentage point reduction in COLAs would reduce total liabilities by 9-11\%, implementing actuarially fair early retirement could reduce them by $2-5 \%$, and raising the retirement age by one year would reduce them by 2-4\%. Even relatively dramatic policy changes, such as the elimination of COLAs or the implementation of Social Security retirement age parameters, would leave liabilities around \$1.5

${ }^{26}$ Bergen and Garcia (2011) indicate that the SEC has been exploring how the state of Illinois has been able to argue that benefit reductions applying only to new hires can be described in a state bond offering as reducing pension contributions immediately and through 2045. 
trillion more than plan assets under Treasury discounting. This suggests that taxpayers will bear the lion's share of the costs associated with the legacy liabilities of state DB pension plans.”

\section{Conclusions}

This brief overview has argued that the recent financial and economic crises have exacerbated the breadth and depth of pension financing challenges by undermining state revenue collections, wounding pension investment performance, and spiking pension liabilities. Fewer active workers remain to support retirees than ever before, and even if equity returns did rise strongly and persistently, it is unlikely that this will happen soon enough to cure the most seriously-challenged plans. Yet it is worth remembering that many state pension problems arose for deeper reasons including the lack of public pension transparency, overreliance on risky asset returns to measure pension liabilities, and inability to meet contribution requirements on a regular basis. As a result, too many U.S. state pension systems have become underfunded, and several face enormous challenges in the not-too-distant future if they are to return to solvency.

As a result of the recent 'perfect storm,' what was once seen as a safe defined benefit promise has now been transformed into a much riskier retirement offering. U.S. state pensions are not guaranteed by federal backing, so it is possible that a public plan might even be unable to continue paying promised benefits. Though modern U.S. history offers no examples of state bankruptcies to date, some municipalities have had to renegotiate their obligations in recent decades. ${ }^{27}$ This in turn raises questions about how public pensions are governed, and whether the existing structures are capable of ensuring managerial oversight of operations and accountability. Pension trustees are the designated 'holders of the pension purse strings,' faced with the difficult

${ }^{27}$ These include Cleveland, Ohio; Bridgeport, Connecticut; and Vallejo, California (c.f. Barclays, 2011). 
challenge of balancing the often-conflicting interests of public sector active and retired workers, taxpayers, and consumers. ${ }^{28}$ Those seeking to remake and strengthen public pensions will need to return the plans to affordability, while making them more resilient to financial, economic, demographic, and political pressures.

${ }^{28}$ For further discussion of public plan governance see Useem and Mitchell (2000) and Yang and Mitchell (2008). 


\section{References}

Angelo, Paul, Keith Brainard, Mitra Drazilov, and Paul Zorn (2010). “Analysis of Joshua Rauh’s Paper, Are State Public Pensions Sustainable?” NASRA. http://nasra.org/resources/RauhResponse.pdf

Bader, Lawrence N. and Jeremy Gold. (2007). "The Case against Stock in Public Pension Funds.” Financial Analysts Journal. 63(1): 55-62.

Barclays. (2011). States’ Pensions: A Manageable Longer-Term Challenge. Barclays Capital Municipal Credit Research Special Report. May 2011

Bergen, Kathy and Monique Garcia. (2011). “SEC Probes Illinois Pension Savings Projections: Securities and Exchange Commission Inquiry Won't Affect Bond Sale Plans, Quinn Says.” Chicago Tribune. January 25.

Black, Fischer. (1989). “Should You Use Stocks to Hedge Your Pension Liability?” Financial Analysts Journal, 45(1): 10-12.

Bohn, Henning. (2011). “Should Public Retirement Plans be Fully Funded?” Journal of Pension Economics and Finance. 10: 195-219

Brown, Jeffrey R., Robert Clark, and Joshua Rauh. (2011). "The Economics of State and Local Public Pensions. Journal of Pension Economics and Finance. 10 (2): 161-172.

Brown, Jeffrey R. and David W. Wilcox. (2009). "Discounting State and Local Pension Liabilities.” American Economic Review. 99(2 ): 538-542.

Civic Federation. (2007). Dedicated Revenue Sources for State Pension Funds: A Civic Federation Brief. Chicago: The Civic Federation. civicfed.org/sites/default/files/civicfed_240.pdf

Clark, Robert. (2011). “State and Local Pension Plans in the United States.” Presented at the International Workshop on Civil Service and Military Pension Arrangements in Selected Countries of the Asia-Pacific. PIE Hitotsubashi University, Tokyo, January 20-21.

Clark, Robert L., Lee A. Craig, and Neveen Ahmed (2009). "The Evolution of Public Sector Pension Plans in the United States." In The Future of Public Employee Retirement Systems. Olivia S. Mitchell and Gary Anderson, eds. Oxford: Oxford University Press: 241-266

Clark, Robert L., Lee Craig, and John Sabelhaus. (2011). State and Local Retirement Plans in the United States. Northampton, MA: Edward Elgar Publishing.

Clark, Robert L. Lee A. Craig, and Jack W. Wilson. (2003). A History of Public Sector Pensions in the United States. Philadelphia: University of Pennsylvania Press. 
Clark, Robert L. and Melinda S. Morrill. (2011). “The Funding Status of Retiree Health Plans in the Public Sector.” Journal of Pension Economics and Finance. Vol 10 (2). 291-314.

Clark, Robert and Melinda S. Morrill. (2010). Retiree Health Plans in the Public Sector: Is There a Funding Crisis? Northhampton, MA: Edward Elgar.

Cooper, Michael. (2011). “Pension Fund Losses Hit States Hard, Data Show.” New York Times, January 5.

Craig, Lee. (2003). “Public Sector Pensions in the United States.” EH.Net Encyclopedia. Edited by Robert Whaples. March 16. eh.net/encyclopedia/article/craig.pensions.public.us

Epple, Dennis and K. Schipper. (1981). "Municipal Pension Funding: A Theory and Some Evidence.” Public Choice. 141-178.

Fitch Ratings. (2011). Enhancing the Analysis of U.S. State and Local Government Pension Obligations. Special Report. February 17.

Gold, Jeremy and Gordon Latter (2009). “The Case for Marking Public Plan Liabilities to Market.” In The Future of Public Employee Retirement Systems. Olivia S. Mitchell and Gary Anderson (eds.). Oxford University Press: 29-57.

Government Accountability Office (GAO, 2008). "State and Local Government Pension Plans: Current Structure and Funded Status.” Statement of Barbara D. Bovbjerg, Director Education, Workforce, and Income Security, before the Joint Economic Committee of the US Congress. Washington, D.C.: July 10.

Government Accountability Office (GAO, 2010). "State and Local Government Pension Plans: Governance Practices and Long-term Investment Strategies Have Evolved Gradually as Plans Take On Increased Investment Risk.” Report to the Ranking Member, Committee on Finance, U.S. Senate.

Government Accounting Standards Board (GASB, 2010). "Preliminary Views of the Government Accounting Standards Board on Major Issues Related to Pension Accounting and Financial Reporting by Employers.” www.gasb.org/cs/ContentServer?c=Document_C\&pagename=GASB/Document_C/GASBDocumentPage \&cid $=1176156938122$

Government Accounting Standards Board (GASB, 2006). "Why Governmental Accounting and Financial Reporting Is and Should Be Different." www.gasb.org/cs/ContentServer?c=Page\&pagename=GASB\%2FPage\%2FGASBSectionPage\&cid=11761 56741271

Greenhouse, Steven. (2011.) “States Lean on Public Workers for Bigger Pension Contributions.” New York Times. June 15. www.nytimes.com/2011/06/16/business/16pension.html 
Harris, Alexandra. (2011). "Illinois Pension Fund uses OTC Derivatives to Recoup Returns, Jeopardizes Pensions.” Medill Report. June 10. news.medill.northwestern.edu/chicago/news.aspx?id=166746\&print=1

Hsin, Ping-Lung and Olivia S. Mitchell. (1994). "The Political Economy of Public Pensions: Pension Funding, Governance, and Fiscal Stress.” Revista de Analisis Economico. Special Issue on Pension Systems \& Reform. P. Arrau \& K. Schmidt-Hebbel, eds. 9 (1) June: 151-168.

Hustead, Edwin C., and Toni Hustead. (2001). "Federal Civilian and Military Retirement Systems.” In Pensions in the Public Sector. Olivia S. Mitchell and Edwin C. Hustead, eds. Philadelphia: University of Pennsylvania Press: 66-104.

Jones, Norman L., Brian B. Murphy, and Paul Zorn. (2009). Actuarial Methods and Public Pension Funding Objectives: An Empirical Examination. Presentation at the Society of Actuaries Public Pension Finance Symposium. May.

Lav, I. and E. McNichol. (2011). "Misunderstandings Regarding State Debt, Pensions, and Retiree Health Costs Create Unnecessary Alarm.” Centre on Budget and Policy Priorities Report. January 20. www.cbpp.org/cms/index.cfm?fa=view\&id=3372

Little Hoover Commission (2011). Public Pensions for Retirement Security. Milton Marks Commission on California State Government Organization and Economy Report. Sacramento: February.

Lucas, Deborah J. and Stephen P. Zeldes (2009). “How Should Public Pension Plans Invest?” American Economic Review Papers and Proceedings. 99(2): 527-532.

Maguire, Steven. (2011). State and Local Government Debt: An Analysis. Washington, D.C.: Congressional Research Service.

Maurer, Raimond, Olivia S. Mitchell and Ralph Rogalla. (2008). “The Victory of Hope over Angst? Funding, Asset Allocation, and Risk-Taking in German Public Sector Pension Reform. "In Frontiers in Pensions Finance. Dirk Broeders, Sylvester Eijffinger, and Aerdt Houben (eds). Edward Elgar: 51-81.

McElhaney, Stephen T. (2009). "Estimating State and Local Government Pension and Retiree Health Care Liabilities.” In The Future of Public Employee Retirement Systems. Olivia S. Mitchell and Gary Anderson, eds. Oxford: Oxford University Press: 19-28.

McGill, Dan M., Kyle N. Brown, John J. Haley, Sylvester J. Schieber, and Mark Warshawsky. (2010). Fundamentals of Private Pensions $9^{\text {th }}$ ed. Oxford: Oxford University Press.

Miller, Gerard (2008). "Presentation by Girard Miller: Comments before the Public Interest Committee of the American Academy of Actuaries.” Washington, D.C.: Academy of Actuaries. September

4. http://www.actuary.org/events/2008/forum_statements_sept08/oral/miller.pdf 
Mitchell, Olivia S. (2000). “Developments in Pensions.” In Handbook of Insurance. G. Dionne, ed. Boston: Kluwer Academic Publishers: 873-899.

Mitchell, Olivia S. and Gary Anderson, eds. (2009). The Future of Public Employee Retirement Systems. Oxford: Oxford University Press.

Mitchell, Olivia S. and Ping-Lung Hsin. (1997). "Public Sector Pension Governance and Performance". In The Economics of Pensions: Principles, Policies, and International Experience. S. Valdes-Prieto, ed. Cambridge: Cambridge University Press: 92-126.

Mitchell, Olivia S. and Edwin Hustead, eds. (2000). Pensions for the Public Sector. Philadelphia, PA: University of Pennsylvania Press.

Mitchell, Olivia S., David McCarthy, Stanley C. Wisniewski, and Paul Zorn. (2000). "Developments in State and Local Pension Plans." In Pensions for the Public Sector. Olivia S. Mitchell and Edwin Hustead, eds. Philadelphia, PA: Univ. of Pennsylvania Press: 11-40.

Moody's. (2011). Combining Debt and Pension Liabilities of U.S. States Enhances Comparability. New York: Moody’s Investor Services, January 26.

Munnell, Alicia H., Jean-Pierre Aubry, and Laura Quinby. (2010). "The Impact of Public Pensions on State and Local Budgets.” CRR Brief 13, October.

Munnell, Alicia H., Jean-Pierre Aubry, and Laura Quinby. (2011a) "Public Pension Funding in Practice.” Journal of Pension Economics and Finance. 10 (2): 247-268.

Munnell, Alicia H. Jean-Pierre Aubry, Josh Hurwitz, Madeline Medenica, and Laura Quinby. (2011b). “Funding of State and Local Pensions in 2010.” Boston: Center for Retirement Research 17.

Munnell, Alicia, Kelly Haverstick, and Jean-Pierre Aubry (2008). "Why Does Funding Status Vary Among State and Local Plans?” Boston College Center for Retirement Research Brief.

National Association of State Retirement Administrators (NASRA; nd). Public Fund Scorecard, www.publicfundsurvey.org/publicfundsurvey/scorecard.asp

National Council on Public Employee Retirement Systems (NCPERS) and Cobalt Community Research. (2011). The 2011 NCPERS Public Fund Study: Preliminary Results. NCPERS.

National Education Association (NEA). (2004) NEA Issue Brief on Pension Protections in State Constitutions. NEA Collective Bargaining \& Member Advocacy.

Novy-Marx, Robert and Joshua D. Rauh. (2009). “The Liabilities and Risks of State-Sponsored Pension Plans.” Journal of Economic Perspectives 23(4): Fall: 191-210. 
Novy-Marx, Robert and Joshua D. Rauh. (2011a). "Policy Options for State Pension Systems and Their Impact on Plan Liabilities.” Journal of Pension Economics and Finance. 10(2): 173-194.

Novy-Marx, Robert and Joshua D. Rauh. (2011b). "Public Pension Promises: How Big Are They and What Are They Worth? Journal of Finance. Forthcoming.

Novy-Marx, Robert and Joshua D. Rauh. (2011c). “The Revenue Demands of Public Employee Pension Promises.” Kellogg School of Management Working paper, June.

Park, Youngkyun. (2009). “Public Pension Plan Asset Allocations.” EBRI Notes. April 30(4).

Pension Benefit Guaranty Corporation (PBGC, nd). "Plan Termination Fact Sheet.” Washington, D.C.: PBGC. www.pbgc.gov/res/factsheets/page/termination.html

Peskin, Michael. (2001). “Asset/Liability Management in the Public Sector.” In Pensions in the Public Sector. Olivia S. Mitchell and Edwin Hustead (eds.) Philadelphia: University of Pennsylvania Press: 195-217.

Pew Center on the States. (2010a). Roads to Reform: Changes to Public Sector Retirement Benefits Across States. Pew Center: Washington, DC, November.

Pew Center on the States. (2010b). The Trillion Dollar Gap. Pew Center: Washington, DC, November.

Pew Center on the States. (2011). The Widening Gap: The Great Recession's Impact on State Pension and Retiree Healthcare Costs. Pew Center: Washington, DC, April.

Rauh, Joshua D. (2010). "Are State Public Pensions Sustainable? Why the Federal Government Should Worry About State Pension Liabilities.” May 15. ssrn.com/abstract=1596679

Rowl, Daryl. (2011). "Follow the Exit Signs." Columbus Dispatch.com, June 26. www.dispatch.com/live/content/local_news/stories/2011/06/26/follow-the-exit-signs.html?sid=101

Russek, Frank. (2011). The Underfunding of State and Local Pension Plans. Economic and Budget issue Brief. Congressional Budget Office. May.

Schieber, Sylvester J. (2011). "Political Economy of Public Sector Retirement Plans.” Journal of Pension Economics and Finance. 10 (2): 269-290

Segal Associates. (2011). Actual Cost vs Market Price: Does Market Valuation of Pension Liabilities Fit the Public Sector? Washington, DC: Segal Report. June.

Skeel, David. (2011). “A Bankruptcy Law - Not Bailouts - For the States.” Wall St. Journal, January 18. 
Snell, Ronald K. (2011). Pensions and Retirement Plan Enactments in 2011 State Legislatures. National Council on State Legislatures.

Society of Actuaries (SOA) and American Academy of Actuaries. (2006). Pension Actuary's Guide to Financial Economics. Society of Actuaries and American Academy of Actuaries. www.actuary.org/pdf/pension/finguide.pdf.

Staman, Jennifer (2011). State and Local Pension Plans and Fiscal Distress: A Legal Overview. Washington, D.C.: Congressional Research Service.

Standard and Poor's (S\&P) (2011). U.S. States' Pension Funded Ratios Drift Downward. New York: Global Credit Portal Ratings Direct Report.

Tangel, Andrew. (2011). "NJ Taking Risks to Boost Pension Pool, May Double Up on Alternative Investments.” NorthJersey.com, May 17, 2011

US Census Bureau. (2010). “State and Local Public Employee Retirement System Assets Drop Nearly \$180 B in 2008 Census Bureau Reports.” US Department of Commerce Press Release. March 25. www2.census.gov/govs/retire/fy08pressrelease.pdf

Useem, Michael and Olivia S. Mitchell. (2000). "Holders of the Purse Strings: Governance and Performance of Public Retirement Systems”. Social Science Quarterly. 81(2) June: 489506.

Walsh, Mary Williams. (2011). “Two Rulings Find Cuts in Public Pensions Permissible.” New York Times. June 30.

Wilcox, David. (2008). 'The Disclosure of Market Value of Assets and Liabilities by PublicSector Defined-Benefit Pension Plans: Comments before the Public Interest Committee of the American Academy of Actuaries.' Washington, D.C. September 4. www.actuary.org/events/2008/forum_statements_sept08/oral/wilcox.pdf

Wilshire Consulting. (2011). 2011 Wilshire Report on State Retirement Systems Funding levels and Asset Allocation. Santa Monica: Wilshire Consulting.

Winklevoss, Howard E. (1993). Pension Mathematics with Numerical Illustrations. Philadelphia: University of Pennsylvania Press.

Yang, Tongxuan (Stella) and Olivia S. Mitchell. (2008). "Public Pension Governance, Funding, and Performance: A Longitudinal Appraisal." In Pension Fund Governance: A Global Perspective on Financial Regulation. John Evans and John Piggott, eds. Cheltenham, UK: Edward Elgar: 179-199. 
Table 1. Present Value of Aggregate State DB Plan Liabilities, Alternative Scenarios

\author{
Assumed Discount Rate \\ State-Chosen $^{\mathrm{a}}$ \\ (1) Total Plan Liabilities* \$2.80 trillion \\ (2) Total Plan Assets ** \$1.94 trillion \\ Difference (1-2) \\ Notes: \\ Taxable Muni ${ }^{\mathrm{b}}$ \\ \$3.21 trillion \\ $\$ 1.94$ trillion \\ $\$ 1.27$ trillion \\ Treasury $^{\mathrm{c}}$ \\ $\$ 5.20$ trillion \\ $\$ 1.94$ trillion \\ $\$ 3.26$ trillion \\ * Plan liabilities measured using the Accumulated Benefit Obligation (ABO) accrual \\ methodology; see Rauh (2010). \\ **Assets estimated as of 12/08 \\ ${ }^{a}$ Benefits discounted at the state-chosen discount rate, usually $8 \%$. \\ ${ }^{\mathrm{b}}$ Benefits discounted at municipal bond rates based on zero-coupon municipal yield curve as of \\ 1/30/99. \\ ${ }^{\mathrm{c}}$ Benefits discounted at the zero-coupon Treasury yield curve as an approximation for a default- \\ free rate. \\ Source: Rauh (2010) Table 1.
}

Table 2. Year of Public Plan Exhaustion for Alternative Asset Returns, under Ongoing and Termination Scenarios

Assumed Return on Assets Ongoing Termination

$\begin{array}{ccc}6 \% & 2025 & 2022 \\ 8 \% & 2029 & 2025 \\ 10 \% & 2035 & 2029\end{array}$

Notes: See text for definitions.

Source: Munnell et al. (2011a) Table 4 
Figure 1. Anticipated Year of Exhaustion for State Pension Fund Assets

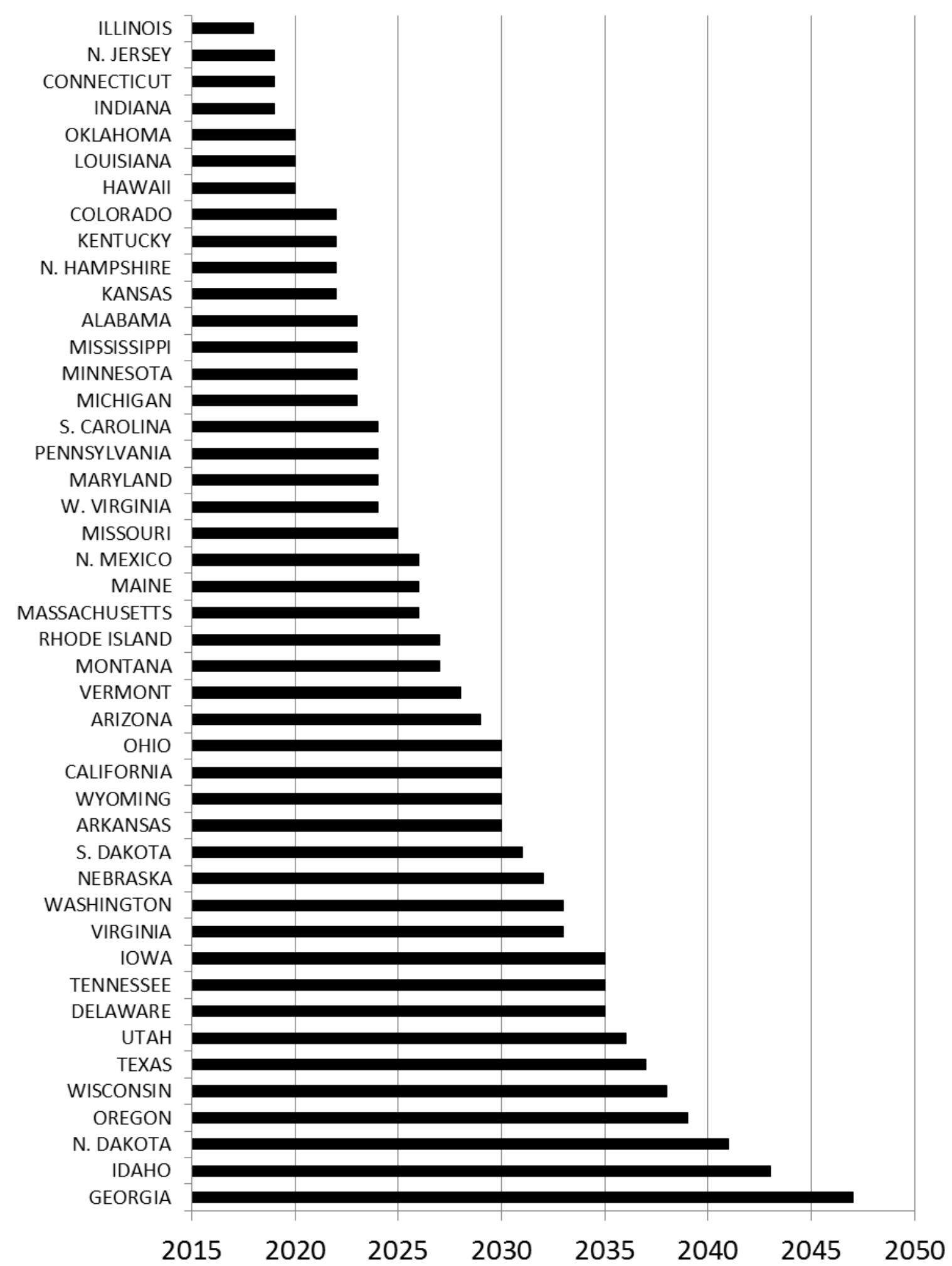

Note: Projections assume the funds earn $8 \%$ on assets and all future contributions are used to pay for new benefits in full. Source: Derived from Rauh (2010: Table 1) 